active and semi-active volcanoes. An earthquake with epicentre some two miles south-east of Rabaul (New Britain) occurred on May 7, 1919, in the neighbourhood of the semi-active volcano Glaie or Tavurur. One previous to this was on January 1, 1916. The line of disturbance is south-west from the volcano Glaie to the large active volcano called the Father on the north coast of New Britain. Earthquakes appear to be most severe when the Father is quietest. The line extends then westerly towards the west end of New Britain, where there are semi-active volcanoes; thence on to the island of Manam off the coast of New Guinea, where there is a very active volcano. The present seismic activity appears either to be on another branch of this line of activity, or along a westward extension of the line.

\section{Earthquake in the Philippines}

As earthquake of considerable severity was registered at both the Riverview and Perth Observatories in Australia on April 9 early in the day. At Perth the seismograph pendulum boom swung five inches, and at Riverview the seismograph showed earthquake waves passing the observatory for four hours. It was tentatively suggested that the earthquake might have had its epicentre under the sea south-west of Luzon in the Philippines.

\section{Rainfall Flooding and Health}

A CHADwick Lecture under the Bossom Gift was given on April 14 by Mr. D. C. Graham, who discussed the dangers from rainfall in urban areas, the prevention of flooding of buildings and of its insanitary consequences. Mr. Graham dealt with the subject under four headings: (1) faulty design of buildings and omissions of essentials ; (2) overflowing of streams and rivers; (3) damp and flooding by land water; (4) backing up of rainwater in drains and sewers. The first two causes were touched on and the two last discussed in detail. Reference was made to the importance of the building by-laws in this connexion and to the necessity of careful inspec. tion and repair of river walls. As regards the third ceuse, there is considerable difficulty in ascertaining in dry weather whether a building site will remain dry and whether there are any land drains or filled-in ditches that will cause dampness or flooding after heavy rain. The varying levels of the land water due to drought, pumping near the site and to wells and the great importance of constructing the lowest floors of building either above the maximum water level or making the walls and floors waterproof and of sufficient strength, were dealt with, as well as the laying of sub-soil drains near a building, and what they should and should not do. It is not practicable for financial and other reasons to provide sewers of sufficient capacity to carry away the heavy rainfalls that occur from time to time, especially during thunderstorms, as rapidly as they fall, and there are a number of unknown factors, such as the storage capacity of the sewers and drains and the fact that during a storm the flow in the sewers may be backwards as well as forwards, which prevent precise calculations being made. Where it is necessary to construct basements with floors below the possible flood level in the sewers, there are advantages in not draining such basements; where such basement drainage is required in old or new buildings, the risk of flooding can be reduced to a minimum at no great expense.

\section{Freshwater Fish Farming}

The Freshwater Biological Association of the British Empire has just published a pamphlet on the "Production of Freshwater Fish for Food" by Dr. T. T. Macan, Dr. C. H. Mortimer and Dr. E. B. Worthington (Freshwater Biological Association, Wray Castle, Ambleside, Westmorland, Sci. Pub. No. 6, pp. 36. Price to non-members 1s. 6d.) Fresh water covers about 340 square miles in England and Wales and about a similar area in Scotland. The total area is, therefore, comparatively small; but in war-time these inland waters should not be neglected since they can yield crops of food at the cost of little labour. The chief aim of the pamphlet is to make available some of the methods, especially those involving the use of manures, by which crops of fish from fresh water can be increased. The most suitable fish for stocking ponds are carp (Cyprinus carpio), tench (Tinca tinca) and rainbow trout (Salmo irideus). Other freshwater fish are considered, though most of them are unsuitable for rearing in ponds. Perch, for example, tend to become too numerous, and a method of perch trapping is described in the pamphlet (see also Nature, 148,651; 1941). Improvements in eel fishing are also discussed. Other topics considered in the pamphlet are: the food chain in natural waters, productivity of natural waters, methods of increasing productivity, pond management and construction, stocking and cropping, lay-out of a carp farm, sowage fishponds. Anyone possessing a pond or concerned in any way with areas of fresh water of reasonable size should obtain a copy of this pamphlet.

\section{Air-raid Damage and Electricity Supply}

IN its issues of March 13 and 20, the Electrical Review publishes the results of a works investigation by E. A. Beavis of cable breakdowns due to bomb damage and the resulting short-circuits, the implications of which, on a cable of comparatively small cross-section, seem to warrant careful consideration by power distribution engineers (see also NATURE of February 7, p. 173, and March 28, p. 362). This cable, having an area of $0.023 \mathrm{sq}$. in., was insulated for $11 \mathrm{kv}$. and provided with a B.O.T. sheath and a lead sheath which was double steel-tape armoured and served. It had operated since 1926 on a $6.6 \mathrm{kv}$. system. During a severe raid, a bomb explosion damaged the cable at a point $708 \mathrm{yd}$. from the main sub-station and also a $0 \cdot 10$-sq. in., $3-$ core, $6 \cdot 6 \mathrm{kv}$. cable running close by along the same route. The switch controlling the $0 \cdot 023$-sq. in. cable did not trip, although the $0 \cdot 10$-sq. in. cable was tripped out on short-circuit protection. Excavation disclosed damaged places in the $0 \cdot 023$-sq. in. cable at five points within a distance of about $150 \mathrm{yd}$. from the main sub-station. The faults were cut out and removed for examination. With the exception of No. 5-the farthest from the station-all the failures showed similar characteristics and in appearance were more like bursts or blow-outs than true electrical faults.

At fault No. 5 the cable had burst completely, one steel tape only holding the parts together. At the break, the conductor strands showed signs of fusing, while the lead sheath also had been partly melted. a short-circuit had evidently occurred at this par. ticular spot. From the collected evidence, it seems that two distinct breakdowns occurred, the first of which was at the crater caused by the explosion and 